\title{
Patterns of smoking in Spain
}

\section{Results from a regional general population survey}

\author{
M.C. Del Río \& F.J. Alvarez \\ Drugs and Alcohol Research Group, Faculty of Medicine, University of Valladolid, Valladolid, Spain
}

Accepted in revised form 12 July 1994

\begin{abstract}
Smoking patterns were examined in 2500 individuals, aged 14-70 years living in Castille and Leon (Spain) in the fall of 1992. Of these, $39.6 \%$ were regular smokers, $7.2 \%$ were occasional smokers, $14.8 \%$ were former smokers, and $30.4 \%$ were non-smokers. Sex differences were striking:
\end{abstract}

there was a higher prevalence of regular smokers among males than females, males smoked much more, and were more frequently French-type cigarette smokers. A comparison of the present figures with data from an earlier survey carried out in 1989 suggests that smoking is decreasing in Spain.

Key words: Population surveillance, Smoking-epidemiology, Spain

\section{Introduction}

The information available concerning smoking patterns and figures for developed countries show that Spain is one of the countries in which smoking is more common [1-3]. Different cross-national and regional studies carried out in Spain throughout the 1980s showed a prevalence of smoking, ranging from $54 \%$ to $36 \%$ in the different studies [4-10]. An analysis of smoking trends in our country revealed an increase in female smoking [11], and an increase in preference for smoking Virginia-type cigarettes $[12,13]$. It is noteworthy that two of the groups most involved in developing anti-smoking policies, physicians and teachers, showed higher rates for smoking $[1,14]$.

As presumed, these high smoking rates are related to a high economic, social and medical cost. Research on the economic consequences of tobacco consumption in Spain showed that if smoking were to decrease by $10 \%$ in a single year, Spain would achieve a saving of $0.2 \%$ of the gross domestic product [15]. Tobacco-related mortality based on 1983 figures revealed that 39,816 deaths were related to smoking in that year, $13 \%$ of total deaths; $20.3 \%$ among males and 5.4\% among females [16].

The aim of the present study was to analyse the patterns of tobacco consumption among the general population of Castille and Leon (Spain), the trends observed with regard to earlier studies, and to evaluate their possible repercussions on health care and public health.

\section{Materials and methods}

The questionnaire used included items on sociodemographic data and tobacco consumption: smoking frequency, preferences, amount and age at which the respondent started smoking.

People aged between 14 and 70 years and living in Castille and Leon (Spain) were the target population. Castille and Leon is the largest region in Spain, accounting for nearly $19 \%$ of Spain's size, with a population of about 2,545,926 inhabitants in 1991 (about $6.5 \%$ of the Spanish population). The sample was derived from the population census data of 1991. A sample of 2,500 individuals was selected. The sample was first stratified proportionally by the number of the inhabitants of the communities, according to the criteria of the Spanish Institute of Statistics: $250,000-500,000$ inhabitants; 100,000 250,$000 ; 50,000-100,000 ; 10,000-50,000$; and less than 10,000 inhabitants. Second, the sample was classified by county on the basis of the administrative division of the region (nine counties in Castille and Leon), proportionately to the population of each county. Third, the sample was set out in age groups: $14-19$ years $(\mathrm{n}=327), 20-29(\mathrm{n}=557), 20-39(\mathrm{n}=$ $415), 40-49(n=365), 50-59(n=443)$, and $60-70$ years old $(n=393)$ and, finally, by sex in each one of the mentioned age groups (males, $\mathrm{n}=1,243$; females, $\mathrm{n}=1,257$ ).

The interviews were conducted by trained assistants in the fall of 1992. About 300 people in total refused to answer the questionnaire. Those who refused to participate in the survey were replaced by another individual of the same age group and sex. Few people, about 50, started the interview but did not complete it. In all cases, the questionnaires were 
checked later by a supervisor for completeness and accuracy. Out of 2,700 interviews carried out, 200 were rejected mainly for not answering relevant parts of the questionnaire or for inconsistent answers.

The analysis of the data was carried out in the Data Processing Center at The University of Valladolid, using the statistical package SAS, 6.07 version (under the VAX/VMS 5 version).

\section{Results}

Table 1 shows the percentages of regular - daily smokers $(39.6 \%)$, occasional smokers $(7.2 \%)$, former smokers $(14.8 \%)$ and non-smokers (38.4\%). Significant differences were found between sexes $(p<$ 0.0001 ): there were more males among regular smokers and former smokers, while there was a higher prevalence of non-smoking among females than males (Table 1). The highest prevalence of regular smokers was found in those aged 20-29 $(54.9 \%)$ and $30-39$ years old $(51.3 \%)$; prevalence decreased in the two older groups. Regular female smokers were more frequently found among the younger age groups (Table 1). In addition, as age increased so did the number of former smokers. Nonsmokers were more frequently found among those younger than 20 years or older than 50 (Table 1).

An average of 16.6 cigarettes per day was smoked by regular smokers (Table 2) and the differences by gender were striking: males smoked significantly more than females $(p<0.0001)$. Fifteen percent of regular smokers smoked over 20 cigarettes/day and $44.1 \%$ smoked 11-20 cigarettes/day: in both cases higher figures were found among males $(p<0.0001$, Table 2). Sex differences were found as regards tobacco preferences $(p<0.0001)$. Virginia-type cigarettes were preferred $(57.6 \%$, Table 2$)$, however females smoked Virginia-type cigarettes more frequently than males, while males were evenly split

Table 1. Patterns of smoking in persons $14-70$ years of age, by gender

\begin{tabular}{|c|c|c|c|c|c|c|c|c|c|c|c|c|c|c|c|}
\hline & \multicolumn{3}{|c|}{$\begin{array}{l}\text { Sample distribution } \\
\mathrm{N}\end{array}$} & \multicolumn{3}{|c|}{$\begin{array}{l}\text { Regular smokers } \\
(\%)\end{array}$} & \multicolumn{3}{|c|}{$\begin{array}{l}\text { Occasional smokers } \\
(\%)\end{array}$} & \multicolumn{3}{|c|}{$\begin{array}{l}\text { Former smokers } \\
(\%)\end{array}$} & \multicolumn{3}{|c|}{$\begin{array}{l}\text { Non-smokers } \\
(\%)\end{array}$} \\
\hline & Total & Male & Female & Total & Male & Female & Total & Male & Female & Total & Male & Female & Total & Male & Female \\
\hline Total & 2500 & 1243 & 1257 & 39.6 & 46.9 & 32.3 & 7.2 & 7.6 & 6.7 & 14.8 & 18.9 & 10.8 & 38.4 & 26.5 & 50.2 \\
\hline \multicolumn{16}{|l|}{ Age range } \\
\hline $14-19$ & 326 & 163 & 163 & 30.7 & 28.2 & 33.1 & 18.1 & 17.8 & 18.4 & 3.4 & 3.1 & 3.7 & 47.9 & 50.9 & 44.8 \\
\hline $20-29$ & 557 & 274 & 283 & 54.9 & 53.7 & 56.2 & 7.2 & 8.7 & 5.6 & 7.5 & 7.3 & 7.8 & 30.3 & 30.0 & 30.7 \\
\hline $30-39$ & 415 & 203 & 212 & 51.3 & 56.1 & 46.7 & 7.9 & 7.4 & 8.5 & 14.0 & 17.2 & 10.8 & 26.7 & 19.2 & 34.0 \\
\hline $40-49$ & 366 & 179 & 187 & 43.2 & 63.7 & 23.5 & 6.0 & 5.0 & 7.0 & 15.6 & 17.3 & 13.9 & 35.3 & 14.1 & 55.6 \\
\hline $50-59$ & 443 & 213 & 230 & 31.6 & 46.9 & 17.4 & 3.6 & 6.1 & 1.3 & 20.8 & 24.4 & 17.4 & 44.2 & 23.0 & 63.9 \\
\hline $60-70$ & 393 & 211 & 182 & 18.3 & 29.4 & 5.5 & 2.3 & 2.4 & 2.2 & 28.2 & 43.6 & 10.4 & 50.9 & 24.2 & 81.9 \\
\hline
\end{tabular}

Table 2. Patterns of regular smokers in persons $14-70$ years of age, by gender

\begin{tabular}{|c|c|c|c|}
\hline Regular smokers & $\begin{array}{l}\text { Total } \\
\mathrm{N}(\%)\end{array}$ & $\begin{array}{l}\text { Male } \\
\mathrm{N}(\%)\end{array}$ & $\begin{array}{l}\text { Female } \\
\mathrm{N}(\%)\end{array}$ \\
\hline Total & $988(39.6)$ & $\begin{array}{l}\quad \chi_{1}^{2}=56.6, p<0.0001 \\
583(46.9)\end{array}$ & $405(32.3)$ \\
\hline $\begin{array}{l}\text { Tobacco consumption } \\
1-10 \text { cigarettes/day } \\
11-20 \text { cigarettes/day } \\
\text { Over } 20 \text { cigarettes/day }\end{array}$ & $\begin{array}{l}404(40.9) \\
436(44.1) \\
148(15.0)\end{array}$ & $\begin{array}{l}\quad \chi_{2}^{2}=49.9, p<0.0001 \\
186(31.9) \\
289(49.6) \\
108(18.5)\end{array}$ & $\begin{array}{c}218(53.8) \\
147(36.3) \\
40(9.9)\end{array}$ \\
\hline $\begin{array}{l}\text { Tobacco preferences } \\
\text { French-type cigarettes } \\
\text { Virginia-type cigarettes } \\
\text { French and Virginia-type } \\
\text { Cigars and cigarettes } \\
\text { Pipe tobacco }\end{array}$ & $\begin{array}{c}333(33.7) \\
569(57.6) \\
42(4.2) \\
43(4.3) \\
1(0.1)\end{array}$ & $\begin{aligned} & \chi_{4}^{2}=83.1, p<0.0001 \\
& 247(42.4) \\
& 268(46.0) \\
& 29(5.0) \\
& 38(6.5) \\
& 1(0.2)\end{aligned}$ & $\begin{array}{r}86(21.2) \\
301(74.3) \\
13(3.2) \\
5(1.2)\end{array}$ \\
\hline $\begin{array}{l}\text { Tverage tobacco consumption } \\
\text { (Mean } \pm \text { SD) }\end{array}$ & $16.6 \pm 11.2$ & $\begin{array}{l}F=42.0, p<0.0001 \\
18.5 \pm 12.6\end{array}$ & $13.9 \pm 8.7$ \\
\hline $\begin{array}{l}\text { Starting age for smoking } \\
\quad \text { (Mean } \pm \text { SD) }\end{array}$ & $17.2 \pm 4.5$ & $\begin{array}{r}\mathrm{F}=0.3, p>0.05 \\
17.3 \pm 5.3\end{array}$ & $17.1 \pm 3.2$ \\
\hline
\end{tabular}


between the two types of cigarettes. The mean age for initiating smoking was $17.2 \pm 4.5$ years old (mean $\pm \mathrm{SD})$; there was no significant difference between the sexes $(p>0.05$, Table 2$)$.

\section{Discussion}

The present study shows that smoking is frequent is our region, and that there are striking gender differences in tobacco consumption: there was a higher prevalence of regular smoking among males than females, males smoked significantly more and were more likely to be French-type cigarette smokers, and young females (<29 years of age) were more frequently regular smokers than males. Fifteen percent of regular smokers, $7.3 \%$ of the total surveyed, smoked more than 20 cigarettes per day.

A comparison with the results of a 1989 survey in the same target population and using the same criteria, shows that the number of regular smokers decreased after 1989 by $4.8 \%$, occasional smokers and former smokers increased by $3.3 \%$ and $2.7 \%$, respectively, while the number of non-smokers decreased slightly by $1.1 \%$. Figure 1 shows these trend changes between the sexes. These trend changes from 1989 to 1992 clearly suggest a decrease in smoking and we reported a marked decrease in
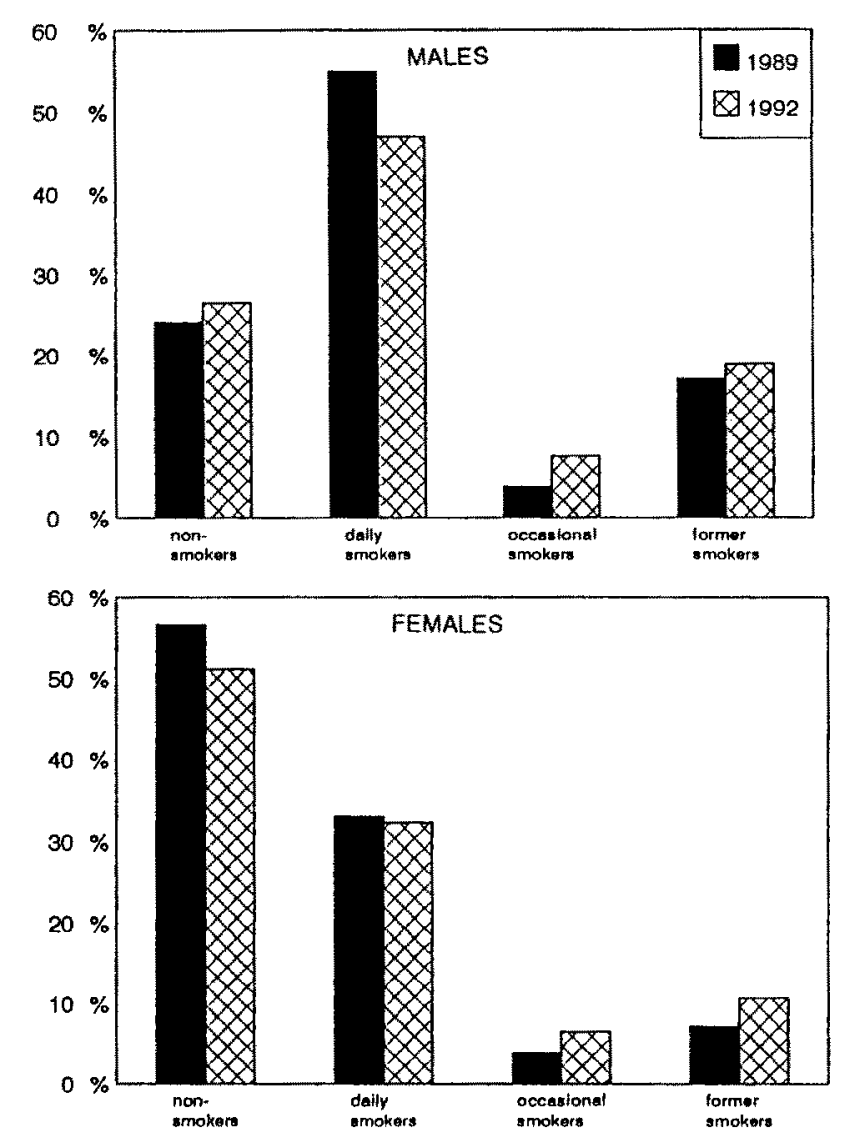

Figure 1. Changes in smoking from 1989-1992 in persons $14-70$ years of age, by gender. smoking among university students from 1984 to 1990 [13]. However, the data available from regional and national studies have not identified this trend: about $40.1 \%$ were regular smokers in 1978 [4], 39\% in 1982 [5]; $41.4 \%$ in 1984 [6] and $41 \%$ in 1985 [7]. These data were obtained from the most significant national studies. A decrease in smoking has been suggested when considering the figures for smokers from the National Health Survey of 1987 (38.1\%) [8], and those obtained in 1989 in a national study about healthy lifestyles (35.9\%) [9]. Nevertheless, figures obtained in other studies $(1988: 39.4 \% ; 1989: 39.2 \%)$ [1] do not support this idea. In any case, the present study is the first one to clearly show a decrease in smoking among the general population in the Castille and Leon region.

This tendency, the decline in smoking habits, is more apparent in the case of men than women (Figure 1). The smoking habit is clearly diminished among men and the percentage of non-smokers, occasional smokers and former-smokers has gone up. However, this decline has not been observed in the case of women or has been less significant than in the case of men [13]. Also, an increase in the number of women who are occasional smokers has been observed, which explains why the figures for nonsmokers went down from 1989 to 1992. It must be pointed out that women smokers are mainly found among the younger age-groups, with a higher educational level and in a higher income bracket $[9,11]$. Contrary to men, the number of former-smokers among women does not increase considerably with age, which coincides with what has been observed in the last studies [9].

Virginia-type cigarettes are those most frequently smoked, especially among women, while men also smoke French-type cigarettes. Previous studies have shown an increasing trend in preference for smoking Virginia-type cigarettes in the last years $[12,13]$. This corresponds to the data obtained from the sale of cigarettes. In 1990, 2,619 cigarettes were smoked per capita, 1,147 for French-type and 1,472 for Virginiatype [17]. In some studies it has also been found that those who smoke Virginia-type cigarettes smoke a greater number of cigarettes than those who smoke French-type ones $[12,18]$. The cigarettes differ as regards flavour, tar and nicotine content. Perhaps nowadays these differences are less apparent due to legislative regulations set up to reduce the tar content in cigarettes (maximum allowed $15 \mathrm{mg}$ ) [19].

Cigarettes are the kind of tobacco most frequently smoked. Men do not only smoke a greater number of cigarettes per day than women, but they are most frequently 'heavy somokers' (over 20 cigarettes/day). This coincides with what has been observed in previous studies. Perhaps it has to be pointed out that the percentage of heavy smokers in the present study $(15 \%)$ is slightly lower than in earlier studies (1978: $18.5 \%$ [4]; 1985: 18\% [7]; 1987: 17\% [8]; 1989: 
$19.3 \%$ [9]), and that the percentage of heavy smokers among women is slightly higher than in the studies mentioned (1978: $3.4 \%$ [4]; 1985: 8\% [7]; 1987: 6\% [8]; 1989: 8\% [9]).

Recently, Spain started developing health policies issued as part of the World Health Organization's 'Health For All' strategy. Therefore, because of the frequency of smoking, smoking-related problems and mortality, the development of policies to stop smoking is relevant. The present study suggests an incipient decreasing trend in smoking in our region. However, because of the still high figures for regular smokers in Spain, a more intensive effort will be needed to reduce smoking if the health goals for the year 2000 are to be achieved. A decrease in smoking and a change of attitudes towards smoking among general practitioners, teachers, and young females represents some of the target groups for such efforts.

\section{Acknowledgements}

This study was supported by a grant from the Junta de Castilla y Leon, Consejería de Sanidad y Bienestar Social, Valladolid, Spain.

\section{References}

1. Sanchez L. Tobacco addiction and control in Spain. Br J Addict 1991; 86: 701-703.

2. Laugesen M, Meads C. Tobacco advertising restrictions, price, income and tobacco consumption in OECD countries, 1960-1986. Br J Addict 1991; 86: 1343-1354.

3. Taket AR, Curtis SE, Thuriaux MC. Ver la santé pour tous dans la région européenne de l'OMS Surveillance des progrès accomplis, III: Modes de vie et milieu physique. Rev Epidém et Santé Publ 1990; 38: 3-18.

4. Anonymous. Encuesta nacional sobre hábito tabáquico. Boletín Epidemiológico Semanal, No. $1502,1979$.

5. Ministerio de Sanidad y Consumo. El consumo de tabaco en la población española mayor de 14 años. Madrid: Ministerio de Sanidad y Consumo, 1982.

6. Navarro J, Lorente S, Varo J, Roiz M (Equipo de Investigacion Sociológica). El consumo de drogas en
España. Madrid: Ministerio de Trabajo y Seguridad Social, 1985.

7. Centro de Investigaciones Sociológicas. Actitudes y comportamientos de los españoles ante el tabaco, el alcohol y las drogas. Revista Española de Investigaciones Sociológicas 1986; 34: 219-243.

8. Ministerio de Sanidad y Consumo. Encuesta nacional de salud. Madrid: Ministerio de Sanidad y Consumo, 1989.

9. Gil E, Jiménez R, Pérez C, Vargas F. Estudio de los estilos de vida de la población adulta española. Madrid: Ministerio de Sanidad y Consumo, 1992.

10. EDIS. Drogodependencias. Madrid: Unión General de Trabajadores, 1987.

11. De Onis M, Villar J. La consommation de tabac chez la femme espagnole. World Health Stat Q 1991; 44: 80-88.

12. Rodríguez ME, Camí J. Substance use among medical students in Barcelona (Spain): A comparison with previous surveys. Drug Alcohol Depend 1986; 18 : 311-318.

13. Alvarez FJ, Del Río MC. Decreasing prevalence of smoking in Spain. Lancet 1993; 341: 119.

14. Sanchez L, Calatrava JM, Escudero C, García A, Marco V, Esteras A. Prevalencia del tabaquismo en la profesión médica. Med Clin 1988; 90: 404-407.

15. Rovira J, Escribano M. Estimación del impacto económico a largo plazo de una reducción del consumo de tabaco. Madrid: Ministerio de Sanidad y Consumo, 1989.

16. González J, Rodríguez-Artalejo F, Martín J, Banegas JR, Villar F. Muertes atribuibles al consumo de tabaco en España. Med Clin 1989; 92: 15-18.

17. Ministerio de Sanidad y Consumo. Indicadores de Salud. Madrid: Ministerio de Sanidad y Consumo, 1993.

18. Alvarez FJ, Queipo D, Del Río MC, García MC. Prevalence of smoking among young people in the rural community of Spain. Med Sci Res 1988; 16: 947-948.

19. Sasco AJ, Dalla-Vorgia P, Van der Elst P. Comparative study of anti-somoking legislation in countries of the European Economic Community. Lyon: International Agency for Research on Cancer, IARC Technical Report No 8, 1992.

Address for correspondence: F. Javier Alvarez, Drugs and Alcohol Research Group, Faculty of Medicine, University of Valladolid, E-47005 Valladolid, Spain

Fax: +3483423022 and +3483423073 